RESEARCH ARTICLE

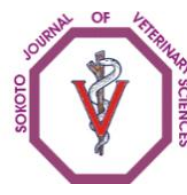

Sokoto Journal of Veterinary Sciences

(P-ISSN 1595-093X/E-ISSN 2315-6201)

Udegbunam \& Udegbunam /Sokoto Journal of Veterinary Sciences (2014) 12(2): 14-18.

http://dx.doi.org/10.4314/sokjvs.v12i2.3

\title{
Anaesthetic potency and physiological effects of refrigerated solution of thiopentone sodium in rabbits
}

\author{
RI Udegbunam* \& SO Udegbunam
}

Faculty of Veterinary Medicine, University of Nigeria, Nsukka-Nigeria

*Correspondence: Tel.:234 8035647718, E-mail:celiaritau@yahoo.com

\begin{abstract}
Several in vitro studies have justified the use of thiopentone solutions beyond the period recommended by the manufacturer. We conducted this in vivo study to investigate the anaesthetic potency and physiological effect of refrigerated thiopentone solution. Rabbits in four groups designated A, B, C and D were anaesthetized using 25 $\mathrm{mg} / \mathrm{kg}$ thiopentone solution stored for 0 (fresh solution), 3, 7 and 14 days in the refrigerator. Anaesthetic potency of the thiopentone solution was determined by monitoring the durations of anaesthesia and recovery time while its physiological effect was assessed by evaluating the changes in the heart and respiratory rates, packed cell volume and blood glucose post injections. The durations of anaesthesia and recovery time in group $A$ were significantly $(P<0.05)$ longer than those obtained in groups $B, C$, and $D$. At 20 min during anaesthesia, heart rates of rabbits in group $A$ and $B$ were significantly $(P<0.05)$ lower than heart rates of rabbits in group $C$. Respiratory rates decreased significantly $(P<0.05)$ in the four groups post induction of anaesthesia. Packed cell volumes (PCV) in all groups decreased significantly $(P<0.05)$ by 10 min post induction while PCV of the groups increased at 30 and $60 \mathrm{~min}$. In the four groups, no significant increase $(P>0.05)$ in blood glucose occurred at 10 min post induction while blood glucose decreased significantly $(P<0.05)$ at $60 \mathrm{~min}$ post induction. Our findings showed that the potency of thiopentone solution decreased with refrigeration. Also significant drop in blood glucose of rabbits occurred post thiopentone injection. Based on these findings, we discourage the use of refrigerated solutions of thiopentone
\end{abstract}

Keywords: Glucose, Rabbits, Refrigeration, Respiratory rate, Thiopentone sodium

Received: 21-06-2013

Accepted: 08-05-2014

\section{Introduction}

Thiopentone sodium is commercially available in sealed ampoules as a powder buffered with sodium carbonate (Branson, 2007). The powder remains stable until expiration (Meyer \& Fish, 2008) while aqueous solutions show steady deterioration (Branson, 2007). Therefore, its manufacturers recommended that solutions should be discarded after 24 hours (Haws et al., 1998; Pottie \& Dart, 2008). The reasons for this recommendation border on concerns about chemical (potency) and physical $(\mathrm{pH})$ stability as well as contamination with infectious agents (Wong et al., 1992). However to save cost and time, many veterinary institutes prepare bulk solutions which are refrigerated and used until they are depleted (Wong et al., 1992; Haws et al., 1998).

Several empirical studies have been conducted to evaluate the potency (Das Gupta et al., 1987), chemical stability (Haws et al., 1998) and sterility (Wong et al., 1992) of stored solution of thiopentone. The results of these studies provided scientific data justifying the use of thiopentone solutions beyond the period recommended by the manufacturer. However despite these in vitro studies, we consider it worthwhile to conduct an in vivo study to investigate the effect of refrigerated solution of thiopentone beyond the recommended 24 hours time limit. 
In this study to ascertain the anaesthetic potency of refrigerated thiopentone sodium we compared the durations of anaesthesia and recovery time produced by freshly reconstituted and stored solution. The effects of the fresh and stored thiopentone solution on the heart and respiratory rates, packed cell volume and blood glucose were also evaluated and compared.

\section{Materials and methods}

Twenty 10 months old clinically healthy male New Zealand white rabbits of mean weight $1.6 \pm 0.2 \mathrm{~kg}$ were used for this study. They were housed individually in metal cages suspended above a concrete floor. Rabbits were kept to acclimatize for 2 weeks to the housing conditions and handling. After acclimatization, they were randomly assigned to four experimental groups $(n=5)$ designated groups $A, B, C$ and $D$. The experiment protocols were approved by the Animal Ethical Committee, University of Nigeria, Nsukka. Pre-experimental blood samples $(1 \mathrm{ml})$ were collected from the jugular vein into bottles with Ethylenediaminetetraacetic acid (EDTA) for the determination of packed cell volume and blood glucose. Packed cell volume (PCV) was determined by the microhaematocrit method (Bain et al., 2012) while blood glucose was determined by the glucose oxidase method (Julio \& Mottola, 1995) using a hand held auto analyzer (Accucheck Adv. II Roche). The heart rate and respiratory rates were also determined. Heart rate was recorded with the help of a stethoscope while respiratory rate was determined by counting the thoracic excursion of the rabbits.

In group A, to induce anaesthesia $25 \mathrm{mg} / \mathrm{kg}$ (1\%) freshly prepared thiopentone solution (Thiopentone, Rotex medica, Germany) was injected through the jugular vein using a $23 \mathrm{G}$ needle. The solution was then stored in an airtight bottle for 14 days in the refrigerator. Subsequently, animals in groups B, C and D were anaesthetized by intravenous injection of $25 \mathrm{mg} / \mathrm{kg}$ thiopentone solutions stored for 3,7 and 14 days.Post inductions of anaesthesia, the following were calculated.

\section{Duration of anaesthesia}

Time from loss of righting reflex to return of righting reflex.

\section{Recovery time}

Time from loss of righting reflex to assumption of standing posture.

\section{Heart and respiratory rates}

These were re-determined at 10, 20, 30 and $60 \mathrm{~min}$ post induction.
Packed cell volume (PCV)

Packed cell volumes of rabbits were re-determined at 10,30 and $60 \mathrm{~min}$ post induction.

\section{Blood glucose}

Blood glucose of rabbits were re-determined at 10 , 30 and 60 min post induction.

\section{Data analysis}

Changes in the heart and respiratory rates, packed cell volume (PCV) and blood glucose over time within groups were studied by comparing the means obtained at the different time points during anaesthesia with their respective baseline mean values using one-way analysis of variance (ANOVA) in SPSS version 15.0. Also the mean values of anaesthetic indices, PCV, glucose, heart rate and respiratory rates obtained were compared between groups using ANOVA. Tukey test was used for Posthoc comparison at probability less than 0.05 .

\section{Results}

The durations of anaesthesia and recovery time in group $A$ were significantly $(P<0.05)$ longer than those obtained in groups $B, C$, and $D$ (Table 1 ).

As shown in Table 2 , slight decrease $(P>0.05)$ in heart rate occurred following injection of thiopentone in groups $A$ and $B$ while heart rates increased slightly $(P>0.05)$ in groups $C$ and $D$. At 20 min during anaesthesia, heart rates of rabbits in group $A$ and $B$ were significantly $(P<0.05)$ lower than heart rates of rabbits in group C. By 30 and $60 \mathrm{~min}$ of anaesthesia, no significant different $(P>0.05)$ was noted in heart rates of the four groups. Respiratory rates of rabbits in all the groups decreased significantly $(P<0.05)$ post induction of anaesthesia. At all time points during anaesthesia, the respiratory rates of all the groups were not significantly $(\mathrm{P}>$ 0.05) different.

Packed cell volume of rabbits in all groups decreased significantly $(P<0.05)$ by 10 min post induction. However PCV of rabbits in the four groups were not significantly $(P>0.05)$ different (Table 3 ). No significant increase $(P>0.05)$ in blood glucose occurred in the four groups at 10 min post induction while the blood glucose decreased significantly $(P<0.05)$ at 60 min post induction. At 30 min post induction, blood glucose of groups $B$ and $C$ were significantly $(P<0.05)$ lower than blood glucose in groups $A$ and $D$ (Table 4). At 60 min post induction, blood glucose of the four groups were significantly $(P<0.05)$ lower than their respective baseline readings. 
Table 1: Anaesthetic indices in groups anaesthetized with thiopentone solution

\begin{tabular}{cccc}
\hline Groups & Storage duration of solution (days) & $\begin{array}{c}\text { Duration of anaesthesia } \\
(\mathbf{m i n})\end{array}$ & $\begin{array}{c}\text { Recovery time } \\
(\mathbf{m i n})\end{array}$ \\
\hline A & 0 & $37.6 \pm 1.7^{\mathrm{a}}$ & $60.0 \pm 2.9^{\mathrm{a}}$ \\
$\mathrm{B}$ & 3 & $28.0 \pm 2.9^{\mathrm{b}}$ & $50.7 \pm 4.7^{\mathrm{b}}$ \\
C & 7 & $25.0 \pm 1.3^{\mathrm{b}}$ & $47.7 \pm 1.7^{\mathrm{b}}$ \\
D & 14 & $21.7 \pm .^{\mathrm{b}}$ & $45.0 \pm 9.8^{\mathrm{b}}$ \\
\hline Superscripts $^{\mathrm{a}, \mathrm{b}}$ in a column indicate significant difference (P<0.05) between the group means
\end{tabular}

Table 2: Vital parameters of rabbits pre and post thiopentone injection

\begin{tabular}{cclllcc}
\hline Studied parameters & Groups & $\begin{array}{l}\text { Baseline } \\
\text { (0 } \mathbf{~} \text { in) }\end{array}$ & \multicolumn{2}{c}{ Time post induction (min) } \\
& & & \multicolumn{1}{c}{$\mathbf{1 0}$} & \multicolumn{1}{c}{$\mathbf{2 0}$} & $\mathbf{3 0}$ & $\mathbf{6 0}$ \\
\hline Hearts rates & A & $266.7 \pm 32.1$ & $250.7 \pm 22.2$ & $253.3 \pm 15.4^{\text {ab }}$ & $259.3 \pm 15.3$ & $268.7 \pm 7.7$ \\
(beats/min) & B & $253.3 \pm 23.6$ & $250.7 \pm 5.8$ & $229.3 \pm 4.7^{\mathrm{a}}$ & $246.0 \pm 10.0$ & $257.3 \pm 15.1$ \\
& C & $229.3 \pm 25.4$ & $268.7 \pm 25.7$ & $286.0 \pm 9.5^{\mathrm{b}}$ & $280.0 \pm 2.3$ & $244.7 \pm 22.3$ \\
& D & $253.3 \pm 11.9$ & $271.3 \pm 35.6$ & $262.0 \pm 12.2^{\text {ab }}$ & $283.3 \pm 7.1$ & $285.3 \pm 7.1$ \\
\hline Respiratory rates & A & $217.3 \pm 15.4$ & $49.3 \pm \pm 2.7^{*}$ & $54.0 \pm 11.4^{*}$ & $47.0 \pm 7.9^{*}$ & $150.7 \pm 43.5$ \\
(breaths/min) & B & $205.3 \pm 38.7$ & $41.3 \pm 5.3^{*}$ & $39.3 \pm 2.9^{*}$ & $41.3 \pm 1.3^{*}$ & $127.3 \pm 31.5$ \\
& C & $240.7 \pm 26.6$ & $53.3 \pm 18.7^{*}$ & $74.7 \pm 27.1^{*}$ & $58.0 \pm 7.2^{*}$ & $172.7 \pm 65.7$ \\
& D & $165.0 \pm 38.6$ & $39.3 \pm 3.7^{*}$ & $50.7 \pm 12.7^{*}$ & $65.3 \pm 25.4^{*}$ & $114.0 \pm 51.2$ \\
\hline
\end{tabular}

Asterisks ${ }^{*}$ in a row indicate significant difference $(P<0.05)$ from baseline (time 0$)$ value.

Superscripts ${ }^{\mathrm{a}, \mathrm{b}}$ in a column indicate significant difference $(\mathrm{P}<0.05)$ between the group mean

Table 3: Packed cell volumes (\%) of rabbits pre and post thiopentone injection

\begin{tabular}{cccccc}
\hline Groups & Storage duration of solution & $\begin{array}{c}\text { Baseline } \\
\mathbf{0}\end{array}$ & $\begin{array}{c}\text { Time post } \\
\mathbf{1 0} \mathbf{~ m i n}\end{array}$ & $\begin{array}{c}\text { induction } \\
\mathbf{3 0} \mathbf{~} \mathbf{~ i n}\end{array}$ & $\mathbf{6 0} \mathbf{~}$ in \\
\hline A & & $38.3 \pm 1.2$ & $34.8 \pm 0.7^{*}$ & $38.0 \pm 1.5$ & $39.7 \pm 1.4$ \\
B & 0 & $39.2 \pm 1.9$ & $35.7 \pm 2.3^{*}$ & $38.7 \pm 4.7$ & $39.2 \pm 2.3$ \\
C & 3 & $38.6 \pm 1.7$ & $35.1 \pm 1.1^{*}$ & $38.3 \pm 2.2$ & $38.6 \pm 1.2$ \\
D & 14 & $39.0 \pm 2.1$ & $35.5 \pm 0.8^{*}$ & $38.7 \pm 1.9$ & $38.3 \pm 0.3$ \\
\hline
\end{tabular}

Asterisks $^{*}$ in a row indicate significant difference $(P<0.05)$ from baseline (time 0$)$ value

Table 4: Blood glucose $(\mathrm{mg} / \mathrm{dl})$ of rabbits pre and post thiopentone injection

\begin{tabular}{cccccc}
\hline Groups & Storage duration of solution & $\begin{array}{c}\text { Baseline } \\
\mathbf{0}\end{array}$ & $\begin{array}{c}\text { Time post } \\
\mathbf{1 0} \text { min }\end{array}$ & $\begin{array}{c}\text { induction } \\
\mathbf{3 0} \text { min }\end{array}$ & $\mathbf{6 0} \mathbf{m i n}$ \\
\hline A & & $138.2 \pm 5.3$ & $141.2 \pm 3.9$ & $135.3 \pm 7.8^{\mathrm{a}}$ & $116.0 \pm 4.0^{*}$ \\
B & 3 & $139.8 \pm 9.3$ & $142.1 \pm 4.8$ & $116.6 \pm 9.9^{b^{*}}$ & $116.7 \pm 8.9^{*}$ \\
C & 7 & $140.2 \pm 16.0$ & $143.2 \pm 6.5$ & $113.0 \pm 13.1^{\mathrm{b}^{*}}$ & $115.7 \pm 6.4^{*}$ \\
D & 14 & $138.8 \pm 12.9$ & $141.8 \pm 2.4$ & $130.3 \pm 6.9^{\mathrm{a}}$ & $104.7 \pm 4.9^{*}$ \\
\hline
\end{tabular}

Asterisks in a row indicate significant difference $(P<0.05)$ from baseline (time 0$)$ value

Superscripts ${ }^{a, b}$ in a column indicate significant difference $(P<0.05)$ between the group means

\section{Discussion}

The five factors considered when evaluating the stability of a drug are chemical, microbiological, physical, therapeutic and toxicological stability (USPC, 1994). This study was centered on the therapeutic effect of refrigerated solution of thiopentone sodium. It was noted that the potency of thiopentone as assessed by the duration of anaesthesia and recovery time decreased progressively with storage. This finding is in consonance with the documentation of Branson (2007) who opined that progressive loss of activity occurs as solution age. However, our finding is at variance with those of previous studies in which refrigerated solution of thiopentone were reported 
to retain their potency for periods up to three months (Wong et al., 1992). According to USP XXII, standard solutions of thiopentone should contain not less than $23.25 \mathrm{mg} / \mathrm{ml}$ of the $25 \mathrm{mg} / \mathrm{ml}$ labelled concentration (USPC, 1994). Thus to meet the criteria for chemical stability, this drug must remain within this specified limit of chemical stability and labelled potency (Haws et al., 1998). Previous studies used more concentrated $2.5 \%(25 \mathrm{mg} / \mathrm{ml})$ solutions compared to $1 \%(10 \mathrm{mg} / \mathrm{ml})$ solution used in this study. We therefore suggest that the rapid loss of potency of the solution used in this study might be linked to the lower concentration of the reconstituted solution. However this claim needs to be further verified.

Thiopentone injection caused increase in heart rates of rabbits in groups injected with thiopentone solution stored for 7 and 14 days (groups C and D) while heart rate of the groups that received fresh solution and 3 days old solution (groups A and B) dropped. The cardiovascular effect noticed in groups C and D were expected. Intravenous injection of thiopentone leads to venodilation and peripheral pooling of blood (Reilly, 1994) as well as decrease in mean arterial pressure (MAP), decrease cardiac output and increase in heart rate (Huang et al., 1997). Proffered reasons for increase in heart rate include baroreflex response to reduction in MAP (Aun et al., 1993), sympathetic nerve stimulation post thiopentone injection (McGrath \& Mackenzie, 1977) and cardio stimulation caused by hypercarbia (Huang et al., 1997). The reason for the reduction in heart rates in group A and B is not clear. However, rapid injection of thiopentone produces high transient concentration of the drug in the myocardium (Huang et al., 1997) and this does not allow enough time for compensatory sympathetically mediated increase in vascular tone (Seltzer et al., 1980; Runciman et al., 1990; Huang et al., 1997). We therefore suspect that the rates of injection used in groups A and B were faster than those used in the other two groups. This might have affected the ability of rabbits in the first two groups to compensate for reduction MAP, thus the drop in their heart rates post injection of thiopentone.

Respiratory depression was observed in all the groups post administration of the drug. Similarly, earlier studies have shown that thiopentone injection caused pulmonary depression (Gaudy et al.,
1983; Huang et al., 1997; Gargiulo et al., 2012). This might lead to hypoxia in spontaneously breathing individuals (Gaudy et al., 1983) as well as slight cardio stimulation (Huang et al., 1997).

The packed cell volumes (PCV) of rabbits were monitored post thiopentone injection to assess both the physiological and adverse effects of the drug. The results obtained showed that during anaesthesia, PCV of rabbits decreased by $10 \mathrm{~min}$ in all groups while subsequent increase was noted from 30 min. Previously, Usenik \& Cronkite (1965) reported that PCV decreased during thiopentone anaesthesia due to splenic sequestration of red blood cells. Going by these reports and the finding of this study, we conclude that the drop in PCV observed at $10 \mathrm{~min}$ was the normal response to thiopentone injection and not an adverse physiological effect.

Glucose homeostasis is maintained by a complex neuroendocrine mechanism (Toso et al., 1993). According to Amar et al. (1993) the increase in blood glucose post thiopentone administration may be a consequence of non-adrenergically mediated increase in hepatic glucose release. Also Toso et al. (1993) demonstrated that plasma concentration of glucose raising hormones (adrenocorticotrophic hormone, cortisol and catecholamine) increased in dogs anaesthetized with thiopentone leading to increase in blood sugar level. This study showed that slight increase in blood glucose level occurred in all groups at $10 \mathrm{~min}$ while glucose level decreased significantly in all groups by 60 min post induction. Other studies have reported an increase in blood glucose after thiopentone injection (Amar et al., 1993; Toso et al., 1993; Lei et al., 2009). No study has shown that blood glucose of animals decreased post thiopentone administration. We suggest that the decrease in blood glucose of rabbits may be due to inhibition of hepatic glucose release. This finding in our opinion is suggestive of an adverse effect.

In conclusion, Manufacturers of thiopentone recommended that solution should be discarded within 24 hours of reconstitution. Our finding showed that the potency of thiopentone solution decreased with refrigeration. Also significant drop in blood glucose of rabbits occurred post thiopentone injection. Based on these findings, we discourage the use of refrigerated solutions of thiopentone. 


\section{References}

Amar D, Shamoon H, Lazar EJ \& Frishman WH (1993). Acute hyperglycaemic effect of anaesthetic induction with thiopentone. Acta Anaesthesiologica Scandinavica, 37(6): 571574.

Aun CS, Sung RY, O'Meara ME, Short TG \& Oh TE (1993). Cardiovascular effects of i.v. induction in children, comparison between propofol and thiopentone. British Journal Anaesthesia, 70(6): 647-653.

Bain BJ, Bates I, Laffan MA \& Lewis SM (2012). Basic haematological techniques In: Dacie and Lewis practical haematology, $11^{\text {th }}$ edition. Churchill Livingstone, Pp 25-57.

Branson KR (2007). Injectable and alternative anaesthetic techniques In: Lumb and Jones Anaesthesia and Analgesia $4^{\text {th }}$ edition (Branson KR, Tranquilli WJ, Thurman JC \& Grimm KA, editors), Blackwell Publishing. UK, Pp 273-300.

Das Gupta V, Gardner SM, Jolowsky CM, Newcomer DR \& Stewart KR. (1987). Chemical stability of thiopentone sodium injection in disposable plastic syringes. Journal of Clinical Pharmacology and Therapeutics, 12(5): 339342.

Gargiulo S, Greco A, Gramanzini M, Esposito S, Affuso A, Brunetti A \&Vesce $G$ (2012). Mice anaesthesia, analgesia and care Part 1: Anaesthetic considerations in preclinical research. ILAR Journal, 53(1):E55-E69

Gaudy JH, Dauthier C \& Galliot M (1983). Ventilatory effects produced by the IV administration of incremental doses of thiopentone in the dog. British Journal Anaesthesia,55(10): 977-984.

Haws LL, Herman N, Clark Y, Bjoraker R and Jones D (1998). The chemical stability and sterility of sodium thiopentone after preparation. Anesthesia and Analgesia, 86(1): 208-213.

Huang YF, Upton RN, Gray EC, Grants C, Zheng D \& Ludbrook GL (1997). The effects of short intravenous infusion of thiopentone on myocardial function, blood flow and oxygen consumption in sheep. Anaesthesia and Intensive Care, 25(6): 627-633.

Julio R \& Mottola HA (1995). Glucose oxidase as an analytical reagent. Critical Reviews in Analytical Chemistry, 25(1): 1-42.

Lei H, Duarte JM, Mlynarik V, Python A \& Gruetter R (2010). Deep thiopentone anaesthesia alters glucose homeostasis but not the neurochemical profile in rat cortex. Journal of Neuroscience Research, 88(2):413-419.

McGrath JC \& Mackenzie JE (1977). The effects of intravenous anaesthetic on the cardiovascular system of the rabbit. British Journal of Pharmacology, 61(2): 199-212.

Meyer RE \& Fish RE (2008). Pharmacology of injectable anaesthetics, sedatives and tranquilizers In: Anaesthesia and analgesia in laboratory animals. (Fish $R C$, Brown MJ, Danneman PJ \& Karas A $Z$ editors), $2^{\text {nd }}$ edition. Elsevier Inc., UK, Pp 27-82.

Pottie RG \& Dart CM (2008). Choosing an injectable anaesthetic agent: Characteristics of thiopentone, propofol, ketamine and alfaxalone in small animal clinical use. Australian Veterinary Practice, 38(2): 5 2-72.

Reilly CS (1994). Intravenous anaesthetic agents: Pharmacology In: Anaesthesia (Nimmo INS, Rowbothan DJ \& Smith G, editors) Blackwell Scientific Publications, Oxford, Pp 87-105.

Runciman WB, Mather LE \& Selby DG (1990). Cardiovascular effects of propofol and thiopentone anaesthesia in the sheep. British Journal of Anaesthesia, 65(3): 353-359.

Seltzer JL, Gerwon JI \& Allen FB (1980). Comparison of cardiovascular effects of bolus vs incremental administration of thiopentone. British Journal of Anaesthesia, 52(2): 527529.

Toso CF, Rodriguez RR, Renauld AR, Marquez AG \& Linarez LM (1993). Adrenocorticotrophic hormone, cortisol and catecholamine concentration during insulin hypoglycaemia in dog anaesthesized with thiopentone. Canadian Journal of Anaesthesia, 40(11): 1084-1091.

United States Pharmacopeia Convention Inc (1994). Stability consideration in dispensing practice In: United States Pharmacopeia: The national formulary. (Tauton, MA \& Rand McNally, editors). $23^{\text {rd }}$ edition, Pp 1957-1959.

Usenik EA \& Cronkite EP (1965). Effects of barbiturate anaesthesia on leukocytes in normal and splenectomized dogs. Anaesthesia and Analgesia, 44(2):167.

Wong CL, Warriner CB, McCormack JP \& Clarke AM (1992). Reconstituted thiopentone retains its alkalinity without bacterial contamination for up to four weeks. Canadian Journal of Anaesthesia, 39(5): 504-508. 